\title{
PENGEMBALIAN KREDIT DALAM HAL MENINGGALNYA DEBITUR PADA LEMBAGA PERKREDITAN DESA (LPD) BUDUK, MENGWI KABUPATEN BADUNG
}

\author{
Ida Ayu Gede Putri Satrianingsih, I Nyoman Putu Budiartha, Ni Made Puspasutari Ujianti \\ Fakultas Hukum Universitas Warmadewa, Denpasar-Bali, Indonesia \\ tugek.putri27@gmail.com, budiarthaputu59@gmail.com, puspa.niwapong@gmail.com
}

\begin{abstract}
Abstrak
Lembaga Perkreditan Desa adalah lembaga keuangan yang berada di desa pakraman yang didirikan berdasarkan peraturan daerah dan awig-awig setempat. Dalam pengembalian kredit, ada saja faktor yang menyebabkan kredit tidak dapat dikembalikan oleh debitur, salah satunya ketika debitur meninggal dunia. Permasalahan yang dikaji dalam penelitian ini adalah faktor-faktor yang menyebabkan debitur tidak dapat mengembalikan kredit pada LPD desa Buduk, serta bagaimana pengembalian kredit pada LPD desa Buduk dalam hal debitur meninggal dunia. Tipe Penelitian yang digunakan adalah tipe penelitian hukum empiris dengan pendekatan masalah seperti pendekatan sosiologis dan pendekatan fakta. Hasil penelitian menggambarkan bahwa faktor yang menyebabkan debitur tidak dapat mengembalikan kredit pada LPD Buduk seperti faktor usaha bangkrut, kemampuan pembayaran debitur, kesehatan debitur, debitur meninggal. Kemudian, Prosedur pengernbalian kredit pada LPD Buduk yakni jumlah pinjaman atau pokok akan dikenakan bunga dari jumlah pokok yang dibayar oleh debitur, apabila debitur meninggal dunia pengembalian kredit dilimpahkan ke ahli waris dengan mengajukan surat kematian terlebih dahulu.
\end{abstract}

Kata kunci: Debitur Meninggal, Lembaga Perkreditan Desa, Pengembalian Kredit.

\begin{abstract}
Village Credit Institution is a financial institution located in the Pakraman village which was established based on regional regulations and local awig-awig. In credit repayment, there are some factors that cause credit cannot be returned by the debtor, one of which is when the debtor dies. The problems examined in this study are the factors that cause the debtor to be unable to return credit to the Buduk Village LPD, and how to return credit to the Buduk Village LPD in the event the debtor dies. The type of research used is the empirical legal research with sociological approach and the fact approach. The results illustrate that the factors that cause the debtor to be unable to return credit to the Buduk LPD are bankruptcy of the business, the debtor's payment ability, the debtor's health, the debtor's death. Then, the procedure of credit refund at the Buduk LPD, namely the amount of the loan or principal will be subject to loan rate from the principal amount paid by the debtor, if the debtor dies, the credit return is delegated to the heirs by submitting a death certificate first.
\end{abstract}

Keywords: Debitor dies, Village Credit Institutions, Credit Refunds.

\section{PENDAHULUAN}

Di zaman modern ini khususnya negara indonesia lembaga keuangan dan bank-bank konvensional memiliki peran yang sangat penting didalarn pembangunan perekonomian negara (Yetti, 2012). Lembaga keuangan tersebut memiliki peran yang sangat besar guna memberi pelayanan kepada masyarakat, walaupun bank-bank sudah banyak berdiri dimana-mana tetapi lembaga keuangan sendiri masih mampu bersaing dengan bank-bank konvensional dalam hal memberikan pelayanan perekonomian. Khususnya di Bali memberikan kemudahan kepada masyarakat khususnya di desa dengan membentuk suatu Lembaga keuangan yang didirikan oleh masyarakat Bali yaitu Lembaga Perkreditan Desa (LPD) yang merupakan gagasan oleh pemerintah daerah provinsi Bali sendiri. Lembaga keuangan tersebut terbentuk setelah mengikuti sebuah seminar yang bertajuk seminar kredit pedesaan di Semarang yang diadakan oleh departemen dalam negeri pada tanggal 20 sampai 21 Februari tahun 1984 (Nurjaya, 2011). Berdasarkan Pasal 1 angka 11 Peraturan Daerah Provinsi Bali Nomor 4 tahun 2012 yang berisi tentang perubahan kedua atas Peraturan Daerah Provinsi Bali Nomor 8 tahun 2002 tentang Lembaga Perkreditan Desa. Lembaga Perkreditan Desa yang selanjutnya disebut LPD adalah lembaga keuangan milik Desa Pakraman yang bertempat di wilayah Desa Pakraman. Dalam hukum positif bentuk hukum yang mudah dipahami sebagai preskripsi (Norma) di dalam 
peraturan perundang-undangan produk badan legislatif yang berfungsi membentuk undang-undang. Karena peraturan perundangan bersifat umum-abstrak di dunia akademik (I. D. G. Atmadja \& Budiartha, 2019).

Secara garis besarnya Lembaga Perkreditan Desa memiliki fungsi sebagai lembaga keuangan komunal milik desa pakraman yang didirikan untuk meningkatkan kesejahteraan krama desa serta mengembangkan perekonomian masyarakat pedesaan di Bali, tetapi khasnya LPD di Bali dengan penempatannya dalam otoritas desa adat atau desa pakraman, bukan dalam otoritas desa dinas seperti yang di lakukan di daerah provinsi di luar Bali (Putra, 2014). Landasan hukum pendirian LPD di Bali adalah berdasarkan Surat Keputusan Kepala Daerah Provinsi Bali Tingkat 1 Bali Nomor 972 tahun 1984 tentang pendirian Lembaga Perkreditan Desa yang pada prinsipnya menyatakan: (a) LPD merupakan alat desa dan unit operasional yang berfungsi sebagai wadah kekayaan desa berupa uang atau surat-surat berharga lainnya dan (b) tujuan didirikannya LPD sendiri untuk rneningkatkan daya beli masyarakat desa dan melancarkan lalu-lintas pembayaran dan pertukaran di desa. Dengan demikian eksistensi LPD di Bali sebagai Lembaga keuangan komunal yang berbasis masyarakat hukum adat yang memang dimaksudkan untuk meningkatkan kesejahteraan warga desa (krama desa) dan perekonomian pedesaan, dan karena itu LPD menjadi bagian dari Lembaga ekonomi milik desa (druwe desa) yang beroperasi dalam wilayah desa dan untuk meningkatkan kesejahteraan krama desa. (Sukandia, 2019).

LPD juga memiliki misi komunitas, untuk menjalankan misi tersebut dibentuklah usaha seperti menerima ataupun menghimpun dana dari krama desa baik dalam benruk tabungan atau deposito, hanya memberikan pinjaman kepada krama desa, menerima pinjaman dari berbagai lembaga-lembaga keuangan maksimum sebesar $100 \%$ dari jumlah modal yang dimiliki LPD, dan menyimpan kelebihan likuiditasnya pada bank pembangunan daerah Bali sebagai bank Pembina LPD (A. T. Atmadja, 2011). Pendirian sebuah LPD bukan hanya untuk kepentingan individual, kelompok orang atau badan usaha namun bagi kepentingan dan kesejahteraan krama desa. Demi kepentingan tersebut maka LPD desa Buduk memberikan kemudahan dalam peminjaman kredit apabila masyarakat desa buduk sedang membutuhkan dana dengan mengikuti beberapa ketentuan-ketentuan di dalamnya misalnya bagi masyarakat desa yang ingin mengajukan kredit harus berasal dari desa tersebut selanjutnya membuat perjanjian dengan pihak LPD setelah seluruhnya terpenuhi dan LPD merasa warga desa buduk memang layak mendapatkan pinjaman maka pihak LPD akan mengeluarkan dana sesuai yang tertera pada perjanjian tersebut. Setelah mendapatkan haknya, debitur tidak dapat melupakan kewajibannya yaitu membayar kembali kreditnya kepada kreditur beserta bunga sesuai waktu yang ditentukan (Oktafiani \& Idris, 2015). Proses pengembalian kredit pada LPD Buduk akan berjalan lancar apabila debitur tepat waktu dalam membayar kredit beserta bunganya, namun jika sesuatu hal terjadi yang tidak terduga baik debitur dan kreditur sehingga menghambat pengembalian kredit seperti halnya debitur meninggal dunia.

Berdasarkan pemaparan latar belakang diatas, maka dapat penelitian dirumuskan untuk mengetahui faktor-faktor yang menyebabkan debitur tidak dapat mengembalikan kredit pada LPD Buduk, dan untuk mengetahui pengembalian kredit dalam hal meninggalnya debitur pada LPD Buduk.

\section{METODE PENELITIAN}

Pada penelitian ini, jenis penelitian yang digunakan adalah penelitian dengan mengkaji permasalahan dari sudut empiris. Penelitian hukum empiris merupakan metode yang mencakup seluruh kenyataan sosial, memandang hukum sebagai sebuah kenyataan, serta berisikan kenyataan kultur. Penelitian ini juga bersifat deskriptif yaitu dimana metode empiris mengkaji law in action. Pada kajian empiris dunianya adalah apa yang terdapat di kenyataan (Ali \& Heryani, 2012). Pendekatan masalah yang digunakan pada penelitian ini adalah pendekatan sosiologis dan pendekatan fakta. Pendekatan sosiologis merupakan metode yang membahas suatu objek yang dilandaskan pada masyarakat yang berkaitan dengan permasalahan dalam penelitian yaitu pengembalian kredit. Sedangkan pendekatan fakta merupakan pendekatan dengan mengumpulkan fakta-fakta yang terdapat langsung di lapangan yang diamati secara metodis untuk dijadikan bahan dalam menunjang penelitian ini.

Adapun mengenai sumber bahan hukum yang digunakan dalam penelitian ini terdapat dua (2) sumber yaitu sumber data primer dan sumber data sekunder (Ali, 1998), sumber data primer yaitu data empiris yang diperoleh secara langsung dari penelitian yang didapatkan dilapangan yaitu 
menyangkut mengenai lokasi penelitian. Badung. Sedangkan, sumber data sekunder yaitu bahan yang memberikan penjelasan tentang bahan hukum primer seperti rancangan undang-undang, hasil-hasil penelitian, pendapat para pakar dan buku. Bahan hukum yang digunakan pada penelitian ini terdiri dari Peraturan Daerah Provinsi Bali Nomor 4 tahun 2012 tentang perubahan kedua atas Peraturan Daerah Provinsi Bali Nomor 8 tahun 2002 tentang Lembaga Perkreditan Desa, undang-undang No. 10 tahun 1998 tentang perubahan atas undang-undang Nomor 7 tahun 1992 tentang perbankan. Penelitian dilakukan di Desa Buduk, Mengwi Kabupaten Badung. Peneliti memilih lokasi ini dikarenakan di daerah ini masih banyak dari masyarakat desa yang terkendala dalam pengembalian kredit dari salah satu anggota keluarganya yang meninggal. Selanjutnya, mengenai teknik pengumpulan data yaitu menggunakan teknik studi dokumen terhadap sumber kepustakaan, membaca, serta melakukan pengelompokan terhadap bahan hukum tersebut dan menggunakan teknik wawancara dengan pendataan yang dilakukan melalui proses interview atau wawancara kepada orang-orang yang terkait dengan permasalahan penelitian tersebut. Analisa bahan sebagai tindak lanjut proses pengolahan data, dari data yang berhasil dikumpulkan baik primer maupun sekunder selanjutnya diolah secara kualitatif sehingga didapatkan data yang relevan dan disajikan secara lengkap.

\section{HASIL DAN PEMBAHASAN}

\section{Faktor-Faktor Penyebab Debitur Tidak Dapat Mengembalikan Kredit Pada LPD Buduk}

Dalam pengembalian kredit, kreditur dan debitur memiliki hak dan kewajibannya masing-masing, hak pokok dari kreditur adalah dengan menerima pengembalian kredit beserta bunganya dan kewajibannya adalah memberikan kredit kepada debitur sedangkan hak pokok dari debitur adalah menerima kredit dari kreditur dan kewajibannya adalah mengembalikan dan membayar kredit ditarnbah bunga dan sesuai waktu yang ditentukan. Apabila hal tersebut tidak ditaati maka akan terjadi ketidakseimbangan dimana debitur tidak dapat mengembalikan kredit sehingga rnenirnbulkan suatu risiko yang disebut sebagai kredit macet atau kredit bermasalah. Kredit macet atau kredit bermasalah terkadang dipersamakan artinya namun keduanya memiliki pengertian yang berbeda, dimana kredit macet merupakan kredit yang sama sekali tidak dapat dibayar oleh nasabah yang memiliki angsuran pokok lebih dari 12 (dua belas) kali angsuran atau pinjaman yang telah jatuh tempo lebih dari 3 (tiga) bulan. Sedangkan kredit bermasalah merupakan kredit yang debitumya tidak memenuhi persyaratan yang diperjanjikan sebelumnya misalnya persyaratan pembayaran bunga, pengambilan pokok pinjaman, pengikatan dan peningkatan agunan dan sebagainya. Sehingga keduanya tidak dapat disamakan, kredit macet dapat merupakan kredit bermasalah namun kredit bermasalah belum tentu dapat dikatakan sebagai kredit macet (Mahmoeddin, 2010).

Berdasarkan hasil wawancara dengan (Kepala LPD Buduk Bapak I Ketut Candu Hadi, SE tanggal 22 Desember 2020). Ketidakmampuan debitur mengembalikan kredit pada LPD Buduk disebabkan oleh beberapa faktor-faktor tertentu yaitu:

1. Faktor Usaha bangkrut

Pada LPD Buduk beberapa debitur mengajukan pinjaman yang dipergunakan untuk membangun atau mengembangkan usahanya, namun seiring berjalannya waktu tidak semua usaha selalu berjalan lancar sehingga mengharuskan debitur untuk menutup usahanya, sedangkan penghasilan dari debitur diperoleh dari has ii usahanya tersebut. Dengan demikian debitur tidak dapat mengembalikan kreditnya pada LPD Buduk.

2. Faktor Kemampuan Pembayaran Debitur

Pada LPD Buduk debitur tidak dapat mengembalikan kredit dikarenakan tidak memiliki pekerjaan tetap atau pekerjaan yang rentan akan pemberhentian apalagi ditambah pada masa ini terdapat covid-19 yang menyebabkan banyak:nya masyarakat yang kehilangan pekerjaan. Apabila debitur tidak bekerja setiap setiap hari atau diberhentikan maka kemampuan dari debitur tersebut untuk membayar kreditnya akan menurun sehingga tidak mampu membayar kreditnya pada LPD Buduk.

3. Faktor Kesehatan Debitur

Pada LPD Buduk Kesehatan debitur sangat berperan penting dalam pengembalian kredit, apabila debitur tersebut rentan dengan penyakit maka kesehatannya akan melemah dan mudah sakit ditambah debitur tidak dapat bekerja mencari penghasilan sehingga mengharnbat dalam pengembalian kredit pada LPD Buduk. 
4. Faktor Debitur Meninggal Dunia

Pada LPD Buduk ketika debitur meninggal dunia namun masih dalam masa pengembalian kredit pada LPD Buduk menjadi salah satu permasalahan dalam pengembalian kredit dimana debitur yang meninggal dunia tentu tidak akan bisa melaksanakan kewajibannya untuk mengembalikan kredit pada LPD Buduk.

\section{Prosedur Pengembalian Kredit Pada LPD Buduk}

Pada pengembalian kredit pasti menggunakan prosedur-prosedur yang harus ditaati oleh debitur dalam pengembalian kreditnya atau kewajiban dalam pembayaran kredit tersebut. Pengembalian kredit dilakukan secara bertahap yang dibayarkan setiap bulannya sesuai dengan perjanjian yang telah dilakukan oleh debitur dan kreditur sebelumnya pada LPD Buduk. Dalam pengembalian kredit pada LPD Buduk debitur diwajibkan membayar pokok ditambah dengan bunganya, pembayaran pokok bunga atau dapat disebut dengan angsuran dibayarkan per bulan tergantung dengan jangka waktu pinjaman. Misalnya dalam peminjaman kredit sejumlah Rp. 10.000.000,00 (Sepuluh Juta Rupiah) dengan bunga yang terdapat di LPD sebesar $2 \%$ sehingga jumlah yang harus dibayarkan perbulan dengan pokok ditambah dengan bunga Rp. 200.000,00,- (Dua Ratus Ribu Rupiah), sehingga pembayaran setiap bulannya akan mengalami penurunan mengikuti sisa saldo dari pinjaman debitur.

Sesuai dengan pengembalian kredit tersebut, debitur tidak boleh lalai dalam pengembalian kredit atau membayar kredit, dikarenakan jika dalam pengembalian kredit debitur lalai atau tidak sesuai dengan ketentuan yang diberikan oleh pihak LPD maka debitur akan dianggap melakukan wanprestasi. Seperti yang diatur dalam Pasal 1243 Kitab Undang-Undang Hukum Perdata (KUHPer) tentang wanprestasi yang dapat juga berarti dengan tidak melakukan sama sekali, melakukan tidak sesuai dengan yang diperjanjikan dan melakukan tetapi terlambat. Misalnya, debitur mengajukan kredit pada LPD Buduk dengan menjaminkan BPKB motor saat akan jatuh tempo maka debitur diwajibkan untuk melakukan kewajibannya yaitu membayar kredit, jika debitur tidak melakukan kewajibannya membayar kredit dalam waktu 3 bulan atau seperti yang disepakati pada awal perjanjian kredit maka jaminan yang digunakan debitur akan disita. Begitu pula dengan debitur yang melakukan kewajiban untuk rnernbayar kredit namun sudah jatuh tempo pembayaran atau sudah lewat maka debitur akan dikenai denda.

Pengembalian kredit oleh debitur tidak boleh melanggar ketentuan dari ketentuan yang diperjanjikan dan berdasarkan prosedur-prosedur yang telah disepakati. Prosedur pengembalian kredit pada LPD Buduk yaitu jumlah pinjaman atau pokok nanti akan ditambah dengan bunga dari jumlah pokok yang akan dibayarkan oleh debitur setiap bulannya, semakin cepat jangka wakru yang dipilih maka semakin besar pembayaran setiap bulannya namun jika semakin lama jangka waktu yang dipilih oleh debitur maka pembayaran setiap bulannya akan semakin sedikit, apabila debitur meninggal dunia prosedur pengembalian kredit pertama-tama dengan menentukan siapa yang menjadi ahli waris yang sudah tertera pada awal perjanjian kredit untuk selanjutnya melanjutkan kewajiban melunasi kredit tersebut, selanjutnya pihak debitur selaku ahli waris akan membuatkan surat kematian atau akta kematian yang diserahkan kepada kreditur agar segala yang berhubungan dengan hak dan kewajiban melunasi kredit akan ditanggungjawabkan seluruhnya kepada ahli warisnya, perpindahan tanggung jawab ini berdasarkan juga surat wasiat yang dibuat oleh pewaris diawal pada saat terjadi perjanjian dengan pihak LPD Buduk agar saat meninggal tidak terjadi kekaburan tanggungjawab.

\section{SIMPULAN DAN SARAN}

\section{Simpulan}

Berdasarkan pembahasan pada di atas, maka dapat ditarik kesimpulan sebagai berikut:

a. Debitur tidak dapat mengembalikan kreditnya dikarenakan terjadinya ketidakseimbangan dimana debitur tidak dapat mengembalikan kredit sehingga menimbulkan suatu resiko yang disebut sebagai kredit macet atau kredit bermasalah. Faktor yang menyebabkan debitur tidak dapat mengembalikan kredit pada LPD Buduk yaitu karena faktor usaha debitur bangkrut dimana debitur memiliki usaha namun dalam perkembangannya usahanya tidak mengalami peningkatan sehingga bangkrut, faktor debitur yang kehilangan pekerjaan, faktor debitur yang tidak mempunyai pekerjaan tetap, faktor Kesehatan debitur dimana menyangkut mengenai kesehatan dari debitur tersebut, dan yang terakhir faktor debitur meninggal dunia dimana debitur dalam masa pengembaliannya telah meninggal dunia. 
b. Prosedur dalam pengembalian kredit pada LPD Buduk yaitu jumlah pinjaman atau pokok akan dikenakan bunga dari jumlah pokok yang akan dibayar oleh debitur setiap bulan, semakin cepat jangka waktu yang dipilih maka semakin besar pembayaran setiap bulannya, namun jika semakin lama jangka waktu yang dipilih oleh debitur maka pembayaran setiap bulannya akan semakin sedikit. Apabila debitur meninggal dunia prosedur pengembalian kredit dengan menentukan siapa yang menjadi ahli waris yang untuk selanjutnya melanjutkan kewajiban melunasi kredit tersebut, selanjutnya pihak debitur selaku ahli waris akan membuatkan surat kematian atau akta kernatian yang diserahkan kepada kreditur agar segala yang berhubungan dengan hak dan kewajiban melunasi kredit akan ditanggungjawabkan seluruhnya kepada ahli warisnya, perpindahan tanggung jawab ini berdasarkan juga surat wasiat yang dibuat oleh pewaris diawal pada saat terjadi perjanjian dengan pihak LPD Buduk.

\section{Saran}

Berdasarkan simpulan di atas, dapat disarankan hal-hal sebagai berikut:

a. Bagi LPD Buduk agar hendaknya dalam memberikan kredit pada nasabah agar menganalisa sesuai dengan pedoman yang sesuai sehingga dapat meminimalisir kemungkinan terjadinya faktor-faktor penyebab kredit macet.

b. Bagi Masyarakat agar lebih memaharni pengembalian kredit pada LPD Buduk jika terjadi kredit macet atau terdapat debitur yang meninggal dunia.

\section{DAFTAR PUSTAKA}

Ali, A. (1998). Menjelajahi Kajian Empiris. Makassar: Kencana.

Ali, A., \& Heryani, W. (2012). Menjelajahi Kajian Empiris terhadap Hukum. Jakarta: Prenamedia Group.

Atmadja, A. T. (2011). Penyertaan Modal Sosial dalam Struktur Pengendalian Intern Lembaga Perkreditan Desa (LPD). Jurnal Ilmuiah Akuntansi Dan Humanika, 1(1).

Atmadja, I. D. G., \& Budiartha, I. N. P. (2019). Sistematika Filsafat Hukum. Malang: Setara Pers.

Mahmoeddin, H. A. (2010). Melacak Kredit Bermasalah. Jakarta: Pustaka Sinar Harapan.

Nurjaya, N. (2011). Landasan Teoritik Pengaturan LPD sebagai Lembaga Keuangan Komunitas Masyarakat Hukum Adat di Bali. Denpasar: Udayana University Press.

Oktafiani, L., \& Idris, I. (2015). Pelaksanaan Pemberian Kredit dengan Jaminan Hak Tanggungan pada Debitur PT. Bank DKI Jakarta Pusat. Lex Jurnalica, 12(2), 79-90.

Putra, B. P. (2014). Pengelolaan Resiko Pada Organisasi Lembaga Perkreditan Desa. Citizen Charter, $1(1), 1-24$.

Sukandia, I. N. (2019). Lembaga Perkreditan Desa (Berbasis Masyarakat Mukum Adat Bali). Jawa Timur: CV. Nuswantara.

Yetti, F. D. (2012). Bank : Studi Komparatif Antara Ekonomi Konvensional Dan Ekonomi Islam. AlFikra : Jurnal Ilmiah Keislaman, 11(1), 133-164. 